\title{
Pengaruh Tingkat Kedisiplinan Terhadap Kinerja Pegawai Pada Kantor Badan Narkotika Nasional (BNN) Kabupaten Tanjung Jabung Timur
}

\author{
Hezza Juni Dirta, Rahmi Handayani \\ Universitas Muhammadiyah Jambi \\ Correspondence email: junidirta.hezza@gmail.com
}

\begin{abstract}
The purpose of this study was to determine the effect of the level of discipline on employee performance at the National Narcotics Agency (NNA) office in Tanjung Jabung Timur district. The variables tested in this study were the level of discipline and employee performance. The sample of this study is the Office of the National Narcotics Agency (NNA) of Tanjung Jabung Timur Regency. The survey was conducted by all 37 NNA employees. Testing the hypothesis in this study using simple regression analysis. Hypothesis testing results indicate that the level of discipline affects employee performance.
\end{abstract}

Keywords: employee performance, level of discipline

\section{Pendahuluan}

Kesuksesan atau kegagalan suatu lembaga atau instansi pemerintah sangat ditentukan oleh faktor Aparatur Sipil Negara sebagai aparatur pemerintah, kualitas Aparatur Sipil Negara kemampuan Aparatur Sipil Negara atau aparatur melaksanakan dan menyelesaikan tugas secara baik dan dapat bekerjasama dengan tingkat produktivitas yang tinggi memungkinkan tujuan lembaga tercapai secara maksimal. Masalah disiplin bagi kalangan Aparatur Sipil Negara negeri sipil sudah ada diatur dengan jelas tentang kewajiban yang harus ditaati dan hak larangan yang tidak boleh dilanggar, sebagaimana yang telah dituangkan pada Peraturan Pemerintah Nomor 53 Tahun 2010 tentang Disiplin Aparatur Sipil Negara Negeri Sipil, memberikan pengertian Disiplin Aparatur Sipil Negara Negeri Sipil adalah kesanggupan PNS untuk menaati kewajiban dan menghindari larangan yang ditentukan dalam peraturan perundang-undangan dan/atau peraturan kedinasan yang apabila tidak ditaati atau dilanggar dijatuhi hukuman disiplin. Salah satu unsur yang mendukung tercapainya tujuan dalam lembaga adalah disiplin yang merupakan cerminan tindakan kesadaran dan itikat baik yang didasarkan atas kepatuhan terhadap peraturan yang berlaku guna tercapainya pelaksanaan tugas dan pencapaian hasil kerja yang berhasil guna dan berdayaguna. Tujuan penelitian untuk mengetahui pengaruh tingkat kedisiplinan terhadap kinerja Pegawai pada Kantor Badan Narkotika Nasional (BNN) Kabupaten Tanjung Jabung Timur

\section{Disiplin kerja}

Menurut Hasibuan (2010) definisi Disiplin adalah kesadaran dan kesediaan seseorang mentaati semua peraturan perusahan, Badan atau lembaga dan norma-norma sosial yang berlaku, sedangkan kesadaran adalah sikap seseorang secara sukarela mentaati semua peratuaran dan sadar akan tugas dan tanggung jawabnya jadi ASN akan mematuhi dan mengerjakan semua tugasnya dengan baik bukan atas paksaan. Kesediaan adalah suatu sikap, atau tingkah laku dan perbuatan seseorang yang sesuai dengan dengan peraturan Lembaga atau Badan yang tertulis maupun tidak.

\section{Kinerja}

"Output drive from processes, human or otherwise" (kinerja merupakan hasil atau keluaran dari suatu proses) menurut Smith dalam Sedarmayanti (2001), sedangkan Mathis et al. (2001) menyatakan bahwa kinerja pada dasarnya adalah apa yang dilakukan atau tidak dilakukan ASN. Kinerja adalah hasil kerja secara kualitas dan kuantitas yang dicapai oleh seorang pegawai dalam melaksanakan tugasnya sesuai dengan tanggung jawab yang diberikan kepadanya (Mangkunegara, 2004). Kinerja sebagai hasil-hasil fungsi pekerjaan/kegiatan seseorang atau kelompok dalam suatu organisasi yang dipengaruhi oleh berbagai faktor untuk mencapai tujuan organisasi dalam periode waktu tertentu, (Tika, 2006).

\section{Metode}

Menurut Sugiyono (2014) Populasi yaitu wilayah generalisasi yang terdiri atas objek/subjek yang mempunyai kuantitas dan karakteristik tertentu yang ditetapkan oleh peneliti untuk dipelajari dan kemudian ditarik kesimpulannya, sedangkan sampel adalah sebagian dari jumlah dan karakteristik yang dimiliki oleh populasi. Populasi dari penelitian ini adalah karyawan kantor Badan Narkotika Nasional (BNN) Kabupaten Tanjung Jabung Timur. Menurut Sugiyono (2014) 
sampel adalah bagian dari jumlah dan karakteristik yang dimiliki oleh suatu populasi. Dalam penelitian ini, peneliti menggunakan teknik pengambilan sampel probability sampling yang mana pengambilan sampel memberikan peluang yang sama kepada setiap anggota populasi untuk menjadi sampel. Metode analisis data yang digunakan dalam penelitian ini adalah analisis regresi sederhana dengan bantuan komputer melalui program SPSS for windows. Regresi linier berganda digunakan untuk menguji hipotesis 1 Persamaan yang digunakan sebagai berikut:

$\mathrm{Y}=\alpha+\beta_{1} \mathrm{X}_{1}+\mathrm{e}$

\section{Hasil}

Tabel 1

Hasil Uji Pengaruh Disiplin Kerja Terhadap Kinerja Pegawai

\begin{tabular}{|c|c|c|c|c|c|c|}
\hline \multirow{2}{*}{\multicolumn{2}{|c|}{ Model }} & \multicolumn{2}{|c|}{ Unstandardized Coefficients } & \multirow{2}{*}{$\frac{\text { Standardized Coefficients }}{\text { Beta }}$} & \multirow{2}{*}{$\mathrm{t}$} & \multirow{2}{*}{ Sig. } \\
\hline & & $\mathrm{B}$ & Std. Error & & & \\
\hline \multirow[t]{2}{*}{1} & (Constant) & 11.741 & 5.183 & & 2.265 & .030 \\
\hline & DK & .224 & .088 & .393 & 2.529 & .016 \\
\hline
\end{tabular}

Sumber; data olahan

Berdasarkan tabel 1 diatas, maka dapat ditulis persamaan regresi sebagai berikut:

$\mathrm{Y}=11.741+0,224 \mathrm{DK}$

Hasil regresi tersebut diperoleh konstanta sebesar 11.741, artinya jika Disiplin Kerja (DK) tidak mengalami perubahan (konstan) maka Kinerja Pegawai (KP) di BNNK Tanjung Jabung Timur sebesar 11.741 Satuan. Selanjutnya setiap kenaikan 1 persen Disiplin Kerja (DK) Pegawai BNNK Tanjung Jabung Timur maka akan menaikan Kinerja Pegawai (KP) di BNNK Tanjung Jabung Timur sebesar 0,224 atau 22,4 persen.

Tabel 2

Hasil Uj iHubunganDisiplin Kerja Dengan Kinerja Pegawai

\begin{tabular}{|l|r|r|r|r|r|}
\hline \multicolumn{1}{|c|}{ Model } & \multicolumn{1}{c|}{ R } & R Square & Adjusted R Square & Std. Error of the Estimate & Durbin-Watson \\
\hline 1 & $.393^{\mathrm{a}}$ & .155 & .130 & 1.23391 & 2.331 \\
\hline
\end{tabular}

Sumber; data olahan

Nilai R sebesar 0,393 menunjukan hubungan yang tidak terlalu kuat antara variabel yang yang mempengaruhi Disiplin Kerja (DK) dengan variabel yang dipengaruhi Kinerja Pegawai (KP) BNNK Tanjung Jabung Timur. Sedangkan nilai $\mathrm{R}^{2}$ sebesar 0,155 menunjukan bahwa15,5 persen perubahan yang terjadi pada Kinerja Pegawai investasi dijelaskan oleh Disiplin Kerja BNNK Tanjung Jabung Timur. Sedangkan sisanya 85.5 persen dijelaskan oleh faktor-faktor lain diluar model tersebut.

Sadiyo (2014) menunjukan bahwa variabel disiplin kerja berpengaruh positif dan signifikan terhadap kinerja pegawai dengan nilai $\beta=0,330$.Kehadiran merupakan hal yang sangat penting peranannya dan sangat dibutuhkan untuk meningkatkan kinerja pegawai. Karena ketika pegawai hadir tepat waktu, maka pekerjaan mereka akan terselesaikan sesuai standar dan hasil yang baik karena sesuai dengan apa yang ada dalam standar yang sudah ditentukan. Berdasarkan daftar kehadiran pegawai, masih tinggi tingkat ketidakhadiran pegawai dalam satu bulan, sehingga bisa mengganggu tanggung jawab pekerjaan. Hal ini tentunya akan berpengaruh terhadap kinerja mereka. Mathis dan Jackson (2010) menyatakan bahwa standar utama dalam mengukur kinerja salah satunya terdapat pengukuran mengenai presences at work (tingkat kehadiran) yaitu asumsi yang digunakan dalam mengukur atau menilai kerja pegawainya dengan melihat daftar hadir.

\section{Simpulan}

Berdasarkan uraian yang telah dijelasakan pada bagian terdahulu, khususnya mengenai hasil-hasil penelitian yang dilakukan penulis, maka selanjutnya dapat dirumuskan suatu kesimpulan, sebagai berikut:

1. Disiplin kerja Pegawai di Kantor Badan Narkotika Nasional Kab. Tanjung Jabung Timur pada dasarnya telah dapat dilaksanakan dengan baik.

2. Kinerja pegawai di Kantor Badan Narkotika Nasional Kab. Tanjung Jabung Timur pada dasarnya telah dapat ditingkatkan dengan baik. 
3. Korelasi antara Pengaruh Disiplin Kerja Terhadap Kinerja Pegawai Kantor Badan Narkotika Nasional Kab. Tanjung Jabung Timur, berdasarkan analisa terdapat pengaruh yang kuat dan menunjukkan bahwa ada pengaruh positif antara Pengaruh Disiplin Kerja Terhadap Kinerja Pegawai. Dan dapat diketahui bahwa antara disiplin kerja pegawai dengan kinerja terdapat pengaruh yang signifikan, dimana semakin baik disiplin kerja pegawai, maka semakin meningkat kinerja pegawai.

\section{Daftar Pustaka}

Gibson, Charles H., Sugiyono. 2014. Metode Penelitian Pendidikan Pendekatan Kuantitatif, Kualitatif Dan R\&D. Bandung: Alfabeta.

Hasibuan, Melayu. 2008. Manajemen Sumber Daya Manusia. Edisi Revisi.Jakarta: PT.Bumi Aksara.

Mathis, R. L., \& Jackson, J. H. 2001. Manajemen Sumber Daya Manusia, terjemahan Jimmy Sadeli dan Bayu Prawira Hie. Jakarta: Salemba Empat

Mangkunegara, A. A., \& Anwar, P. 2004. Manajamen Sumber Daya Perusahaan. cetakan pertama. Bandung: PT. Remaja Rosdakarya.

Sadiyo. 2014. Uji Korelasi Motivasi dan Disiplin Kinerja Terhadap Kinerja Guru Dimoderasi Kepemimpinan Kepala Sekolah.

Sedarmayanti, M.,. 2001. Sumber Daya Manusia dan Produktivitas Kerja. Bandung: Mandar Maju

Tika, P. 2006. Budaya Organisasi Dan Peningkatan Kinerja Perusahaan. Jakarta: PT Bumi Aksara. 